\title{
The Effect of Export Market Orientation in Small and Medium Food Enterprises (SMFEs) Towards International Performance
}

Nurul Ulya Abdul Rahman, Norziani Dahalan@Omar

To Link this Article: http://dx.doi.org/10.6007/IJARBSS/v11-i4/9711

DOI:10.6007/IJARBSS/v11-i4/9711

Received: 21 February 2021, Revised: 23 March 2021, Accepted: 10 April 2021

Published Online: 23 April 2021

In-Text Citation: (Rahman \& Dahalan@Omar, 2021)

To Cite this Article: Rahman, N. U. A., \& Dahalan@Omar, N. (2021). The Effect of Export Market Orientation in Small and Medium Food Enterprises (SMFEs) Towards International Performance. International Journal of Academic Research in Business and Social Sciences, 11(4), 638-649.

Copyright: (c) 2021 The Author(s)

Published by Human Resource Management Academic Research Society (www.hrmars.com) This article is published under the Creative Commons Attribution (CC BY 4.0) license. Anyone may reproduce, distribute, translate and create derivative works of this article (for both commercial and non-commercial purposes), subject to full attribution to the original publication and authors. The full terms of this license may be seen at: http://creativecommons.org/licences/by/4.0/legalcode

Vol. 11, No. 4, 2021, Pg. 638 - 649

Full Terms \& Conditions of access and use can be found at http://hrmars.com/index.php/pages/detail/publication-ethics 


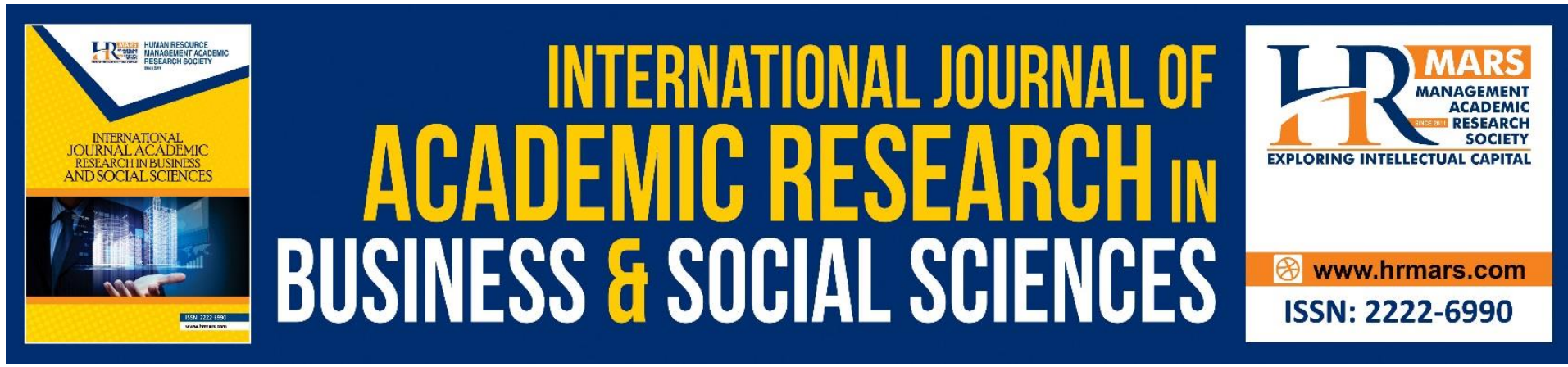

\title{
The Effect of Export Market Orientation in Small and Medium Food Enterprises (SMFEs) Towards International Performance
}

\author{
Nurul Ulya Abdul Rahman, Norziani Dahalan@Omar \\ School of Distance Education, Universiti Sains Malaysia, 11800 Penang, Malaysia. \\ Email: nurululya53@yahoo.com,norziani@usm.my
}

\begin{abstract}
A significant issue for internationalizing SMEs is the improvement of its international performance. To increase performance, several researchers have proposed that businesses must strengthen their export market orientation (EMO); but the way this connection works is quite unexplored. This research examines whether strategic alliances, by which companies' access to information and resources play a mediating role in the EMO and international performance relationship. The population of this study is Malaysian food industry SMEs that are involved in the export activities. The food industry SMEs (i.e. SMFEs) was chosen due to the potential of this industry towards economic growth. A conceptual framework is proposed to identify dimensions of EMO, strategic alliance and international performance. The framework will be used to examine how these variables interact in the context of Malaysia. This is important for both theoretical and practical aspects as its exploration will contribute to a deeper understanding of how SMEs especially in the food industry can improve their international performance strategically and effectively.
\end{abstract}

Keywords: Export Market Orientation, Strategic Alliance, International Performance, SME, Food Industry.

\section{Introduction}

The food industry is one of the vital industries, which contributes towards Malaysia's economic growth. However, there are also challenges for this industry to remain competitive in the market especially when involving international market activities (Malaysia, 2018; Bhuiyan et al., 2017; SME Annual Report, 2018; Zain et al., 2012). The food industry has been dealing with a number of issues, including increased foreign competition, retail chain pressure on price reductions, and an increase in food imports. (Tuzová, Toulová \& Kubíčková, 2017). In Malaysia, the import value of processed foods is amounted to RM 20.7 billion in 2017, which can be considered high for a country (Malaysian Investment Development Authority, 2018).

Most firms cannot prevent from all barriers that may hinder positive international performance of this industry. Yet, firms can seek to minimize the risk and uncertainty of operating abroad by strengthening the internal capabilities of the firms (Paochoo, 2016). To ensure the sustainability and survivability of firms and improvement of performance, internal 
capabilities are required for it to be achieved (Manimala \& Kumar, 2012; Bose, 2016). Additionally, there are numerous discussions in the internationalization literatures that focused on internal capabilities required to develop international performance, which include market orientation (Pascucci, Bartoloni \& Gregori, 2016; Shoham, Rose \& Kropp, 2005; Acosta, Crespo \& Agudo, 2018).

However, the empirical research on the export market orientation and international performance within SMEs is still limited (Olabode, Adeola \& Assadinia, 2018) especially in Malaysia ( Singh \& Mahmood, 2013). This is surprising due to the fact that SMEs' establishments are majority in the country, contributing towards many employment opportunities and GDP to country (SME Annual Report, 2018). Furthermore, Small-and midsized businesses face many barriers that slow them down in international markets. (Paochoo, 2016). While export activities have become one of the vital activities as a key to Malaysia's goal of becoming a high-income country by 2020 (SME Annual Report 2018/17), therefore this research aims to examine the effect of export market orientation on the international performance of SMEs in Malaysia.

Although there was a research that investigated a mutual market orientation and strategic alliances in improving international performance (Nakos, Dimitratos, \& Elbanna, 2018), however it is based on organizational culture, which is more focused on the international market orientation (Narver \& Slater, 1990). This research aims to investigate export market orientation (Cadogan \& Diamantopoulos, 1995) that focuses more on export activities and moderated by domestic strategic alliance as various research have examined international strategic alliance (Brouthers et al., 2015; Nakos et al., 2018). The effect of domestic strategic alliances remains less understood, although strategic alliances are important for the internationalization of the new venture (lurkov \& Benito, 2018;Milanov \& Fernhaber, 2014).

Thus, the overall purpose of the paper is to develop a conceptual framework to assist in identifying the effects of export market orientation (EMO) in mediating domestic strategic alliance to the international performance. This paper outlines the literature review of the relationship of EMO, strategic alliance and international performance. Then, a conceptual framework brings together EMO and postulates the moderating role of domestic strategic alliance, respectively.

\section{Literature Review \\ Challenges of Exporting for Malaysian SMEs}

To remain competitive, previous studies have found that internationalization enhances SME competitiveness and prospects for survival. (Bose, 2016; Zhou \& Wu, 2014). Moreover, internationalization supported innovative capability (Kalinic \& Forza, 2012; Ren, Eisingerich \& Tsai, 2015), as well as improved productivity (Coviello, McDougall \& Oviatt, 2011; Ren, Eisingerich \& Tsai, 2015) of SMEs compared to non-internationalized SMEs. In addition, internationalization, due to diversification advantages, economies of scale and learning advantages, has been a success factor in achieving growth, competitiveness and superior results. (Coviello et al., 2011; Glava et al., 2017).

It is a tendency for smaller firms to seek growth not only depending on the domestic market, but also to obtain their new customers through international venture efforts, as the local market is insufficient to ensure business growth and sustainability. (Tarun Kanti Bose, 2016). Thus, diving into the international market will be a platform for firms to receive global competition benefits and increase survival prospects resulting in becoming a more reliable 
player in the domestic market (Bose, 2016; Zhou \& Wu, 2014). In addition, internationalization will create more employment activities, improve productivity for the national market, and as a way in accumulating foreign exchanges reserves (Hashim, 2015).

Being a small and open economy, Malaysia remains highly vulnerable to external risks and volatility. Malaysia needs to focus on improving productivity, improving innovation and maximizing export potential to strengthen its economic resilience. (Eleventh Malaysia Plan, 2020). Export is commonly viewed as an important contribution to the nation's economic growth and well-being (Ribau et al., 2017). Malaysia External Trade Development Corporation (MATRADE) has also intended to internationalize "export-ready" concept and practice for the food industry (SME Annual Report, 2018). Thus, for the food industry to maintain their business growth and sustainability, it should involve itself in the international business transaction.

As shown in Table 2 and Figure 2, the Malaysian food industry was facing a decline in its export value for the years 2016 to 2017. Moreover, SME Annual report of 2017/2018 has been surveyed among all registered SMEs to recognize the constraints of SMEs in the export operations. Figure 1 illustrated that $53.3 \%$ of SMEs responded that they had inadequate information on the targeted market. A total of $46 \%$ SMEs responded that they had inadequate knowledge on competitors; $43.3 \%$ of SMEs experiencing higher operating cost, $42.9 \%$ faced insufficient knowledge on procedure to export, $40.7 \%$ had insufficient knowledge of global demand; $40.4 \%$ experienced inadequate sources of financing. Therefore, factors that may contribute to a positive international performance of SMEs for the food industry should be analyzed for the business firms to continue surviving in the scarce market.

\section{Constraints in Exporting (\%) for Malaysian SMEs}
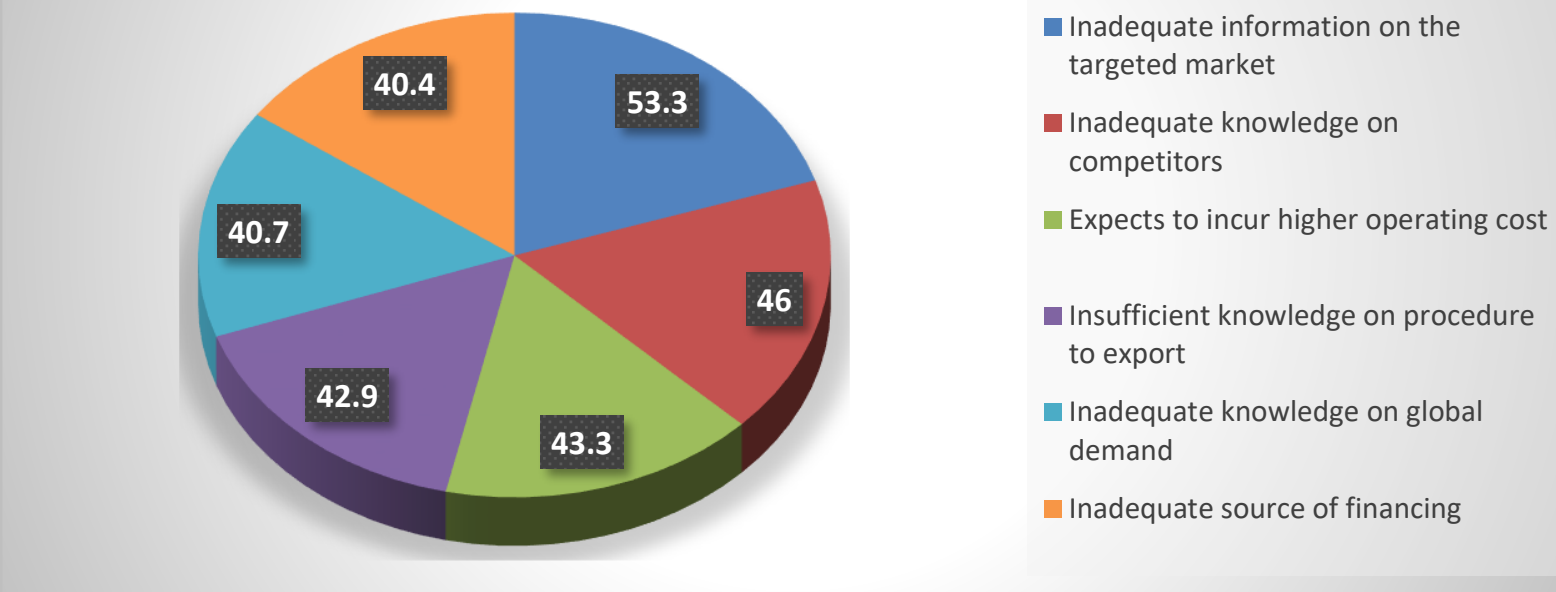

Figure 1: Constraints in SMEs Exporting (\%)

Sources: SME Corp. Malaysia Annual Report, 2017/2018)

\section{Export Market Orientation}

Nowadays, a firm must compete with rising competitors in the market especially for SMEs. To make sure that their presence is still relevant in the market, they must strengthen its domestic and international competitive position with successful internationalization that will enlarge the market for its products or services (Zahra, 2005). Hence, the researchers in recent years, 
attempted to recognize the attributes that permit SMEs to perform better in international market regardless their lack or resources compare to other big companies (Nakos et al., 2018). Past researchers have observed some characteristics that lead to the better performance of a firm and one of them are market orientation.

Market orientation is fundamentally informal organizational mindset that effectively enhancing the firm's business performance and achieve organizational goals (Frösén et al., 2016; Murray et al., 2011; Narver \& Slater, 1990; Solano Acosta et al., 2018). It has been recognized as a promising research topic in the export literature (Leonidou, Katsikeas, \& Coudounaris, 2010). Accordingly, the export market orientation research streams has received growing attention especially in the late decades (ipek \& Tanyeri, 2020). A large number of studies in this regard have been focused on exploring the implications of export market orientation, in which the orientation of export markets has shown a huge impact mainly on the export performance (Cadogan, Kuivalainen \& Sundqvist, 2009; Zhang \& Zhu, 2016)

Amid empirical evidence that emphasises the value of export market orientation within SMEs, several issues have not yet been properly researched. This is particularly true in developing countries like Malaysia. More work must be done to understand the considerable potential for small and medium-sized enterprise to flourish further, particularly in the international market. On this basis, present study has examined the export market orientation to link this gap.

\section{Strategic Alliance}

Preceding research has proven that the internationalization of small and medium enterprises (SMEs) poses many challenges and suffers from resources shortages in the aspects of financial, technical and managerial, when an attempt is made to expand into the foreign market (J. W. Lu \& Beamish, 2001). Therefore, the formation of alliance is vital because it might generate better performance with the information and skills provided from firms involved in these alliances' portfolios (Nakos et al., 2018; Veilleux, S., Haskell, N., 2012). In a year, the number of firms that are engaged in strategic alliance is increasing at an average rate of $25 \%$ (Parise \& Casher, 2003) and based on its significance, comprehensive understandings of strategic alliances is essential and managers should consider to adopt and implement this strategy for better international performance.

Malaysian government creates the public-private sector partnership programmes for SMEs to be competitive in global market and promote international exports (SME Annual Report, 2018) in addition to facilitating collaborations between small and medium-sized businesses to enter into new products and export markets (Malaysia, 2015; Yee Whah Chin \& Ee Shiang Lim, 2018). Nakos et al. (2018) has studied the moderating role of strategic alliance on the relationship between the international market orientation (IMO) and international performance among companies in the United Arab Emirates. It was found that alliances have mediated the IMO-performance relationship.

While plentiful has been discovered on the function of strategic alliance in SMEs internationalization, the existing literature are mostly focused on the international strategic alliance (Brouthers, Nakos \& Dimitratos, 2015; Leiblein \& Reuer, 2004; Nakos et al., 2018). Surprisingly, even an earlier internationalization research has proposed that domestic markets play a main role for firm's success in penetrating into the international market (Johanson \& Mattson, 1988). Nevertheless, this study focuses on the domestic strategic alliance. It has been acknowledged that strategic alliance for SMEs is one of the important 
elements to engage in the internationalization (Nakos et al., 2018; Franco \& Haase, 2016). However the importance of domestic strategic alliance remain less understood (Milanov \& Fernhaber, 2014). According to previous findings, it can be assumed that the domestic strategic alliance can serve as a moderator of the relationship between international performance and export market orientation. As mention by Nakos et al. (2018), future researchers must evaluate the international profitability of SMEs in different kinds of alliances.

\section{International Performance}

Internationalization performance is a multidimensional construct (Y. Lu, Zhou, Bruton, \& Li, 2010 ) that captures the performance of international activities of companies. International performance, generally known as the objective/subjective or financial/non-financial performance measure. However, because most of firms' managers are reluctant to publish confidential company information to outsiders, collecting objective data is very difficult (Gregory \& Richard, 1984). Furthermore, using objective measurement may lead to biased evaluation, since managers are not at ease to provide this confidential information to outsiders (Sapienza, Smith, \& Gannon, 1988a).

In Malaysia, some of the previous scholars have focused more on subjective performance of the SMEs ( Singh \& Mahmood, 2013; Ismail \& Kuivalainen, 2015; Ismail, Mohamed \& Uli, 2013) due to easy information gathering rather than objective performance since some companies are not comfortable to disclose important information, which can be use in research (Arunee Tanvisuth, 2007). It is confirmed in the previous literature that management's assessment of performance appears to be more based on their subjective observations than on objectives measurement (Blesa \& Ripollés, 2008; Madsen, 1989) According to the previous studies, subjective perceptions are closely correlated with the objective findings (L. E. Brouthers, Nakos, Hadjimarcou, \& Brouthers, 2009), thus subjective measurement is suffice to evaluate the international performance. Moreover, it was argued that subjective performance measures are usually more practical when evaluating the SMEs, partly because small firms may refuse to provide unbiased, accurate performance measures (Sapienza, Smith, \& Gannon, 1988b). Table 1 shows the summary of the measurement of internationalization performance. 
Table 1. The summary of the measurement of internationalization performance

\begin{tabular}{|c|c|c|c|}
\hline Author & Respondent & Type of Measurement & Type of Scale \\
\hline $\begin{array}{l}\text { Brouthers et al. } \\
(2015)\end{array}$ & $\begin{array}{l}162 \text { SMEs in US and } \\
\text { UK }\end{array}$ & Subjective & $\begin{array}{l}\text { 7-point Likert } \\
\text { 1=Much lower } \\
\text { 7= Much higher }\end{array}$ \\
\hline $\begin{array}{l}\text { Cavusgil \& Zou } \\
\text { (1994) }\end{array}$ & $\begin{array}{l}202 \text { export ventures } \\
\text { Manufacturing }\end{array}$ & Objective \& Subjective & $\begin{array}{l}\text { 10-Point Likert } \\
\text { Scale } \\
1=\text { Unsuccessful } \\
10=\text { Successful }\end{array}$ \\
\hline $\begin{array}{l}\text { Jantunen, } \\
\text { Puumalainen, } \\
\text { Saarenketo, } \\
\text { Kyläheiko \& Kalevi } \\
\text { (2005) }\end{array}$ & $\begin{array}{l}217 \text { manufacturing } \\
\text { and service } \\
\text { organizations. }\end{array}$ & $\begin{array}{l}\text { Objective } \\
\text { Subjective }\end{array}$ & $\begin{array}{l}\text { 10-point Likert } \\
\text { Scale } \\
1=\text { very } \\
\text { unsatisfied } \\
10=\text { very satisfied }\end{array}$ \\
\hline $\begin{array}{l}\text { Byoungho } \\
\text { \& Hyeon Jeong } \\
(2018)\end{array}$ & 470 Korean SMEs & Subjective & $\begin{array}{l}\text { 7- Likert scale } \\
\text { 1= Strongly } \\
\text { Disagree } \\
\text { 7= Strongly Agree }\end{array}$ \\
\hline $\begin{array}{l}\text { Kayabasi \& } \\
\text { Mtetwa } \\
(2016)\end{array}$ & $\begin{array}{l}443 \text { export } \\
\text { companies operating } \\
\text { in the Aegean region } \\
\text { of Turkey. }\end{array}$ & & $\begin{array}{l}\text { 7- Likert scale } \\
\text { 1= very poor } \\
7=\text { exceptional }\end{array}$ \\
\hline $\begin{array}{l}\text { Nakos et al. } \\
\text { (2018) }\end{array}$ & $\begin{array}{l}94 \text { companies based } \\
\text { in the United Arab } \\
\text { Emirates. }\end{array}$ & Subjective & $\begin{array}{l}7 \text { - Likert scale } \\
1-\text { much inferior } \\
\text { to } 7-\text { much } \\
\text { superior }\end{array}$ \\
\hline $\begin{array}{l}\text { Pascucci, } \\
\text { Bartoloni, } \\
\text { Gregori\&Luca } \\
(2016)\end{array}$ & $\begin{array}{l}300 \text { Italian small and } \\
\text { medium-sized coffee } \\
\text { roasting firms }\end{array}$ & Objective & - \\
\hline $\begin{array}{l}\text { Solano Acosta et al } \\
\text { (2018) }\end{array}$ & 161 Mexican SMEs & Subjective & $\begin{array}{l}\text { 7- Likert scale } \\
1 \text { = complete } \\
\text { disagreement } \\
\text { with the } \\
\text { presented } \\
\text { statement, } \\
7 \text { = complete } \\
\text { agreement }\end{array}$ \\
\hline $\begin{array}{l}\text { Vătămănescu, } \\
\text { Alexandru, Mitan } \\
\text { \& Dabija } \\
\text { (2020) }\end{array}$ & $\begin{array}{l}112 \text { European } \\
\text { industrial small and } \\
\text { medium-sized } \\
\text { enterprises }\end{array}$ & Subjective & $\begin{array}{l}\text { 5- Likert scale } \\
\text { 1= Strongly } \\
\text { Disagree } \\
\text { 5= Strongly Agree }\end{array}$ \\
\hline
\end{tabular}




\begin{tabular}{|l|l|l|l|}
\hline $\begin{array}{l}\text { Chelliah, } \\
\text { Mohamed \& } \\
\text { Yusliza } \\
\text { (2010) }\end{array}$ & $\begin{array}{l}\text { 77 SMEs in the } \\
\text { manufacturing } \\
\text { sector }\end{array}$ & Objectives & \\
\hline $\begin{array}{l}\text { Mohammad, } \\
\text { Knight, \& llan } \\
\text { (2018) }\end{array}$ & $\begin{array}{l}\text { 196 SMEs companies } \\
\text { that active in export } \\
\text { activities }\end{array}$ & Subjective \& Objective & 5- Likert scale \\
\hline $\begin{array}{l}\text { Mohammad, } \\
\text { Ramayah, } \\
\text { Soto-Acosta, \& } \\
\text { Lee } \\
\text { (2020) }\end{array}$ & $\begin{array}{l}\text { 119 Malaysian SMEs } \\
\text { that active in export } \\
\text { activities }\end{array}$ & Subjective \& Objective & 5- Likert scale \\
\hline $\begin{array}{l}\text { Huoy } \\
\text { (2018) }\end{array}$ & $\begin{array}{l}\text { 121 Malaysian food } \\
\text { processing SMEs }\end{array}$ & Subjective & - \\
\hline $\begin{array}{l}\text { Noor Azlin \& } \\
\text { Kuivalainen } \\
\text { (2015) }\end{array}$ & $\begin{array}{l}\text { 174 SMEs in the } \\
\text { halal food } \\
\text { manufacturing } \\
\text { sector }\end{array}$ & Subjective & 5- Likert scale \\
\hline $\begin{array}{l}\text { Singh \& } \\
\text { Rosli } \\
\text { (2013) }\end{array}$ & $\begin{array}{l}\text { 201 exporting } \\
\text { manufacturing } \\
\text { SMEs. }\end{array}$ & Subjective & 7- Likert scale \\
\hline
\end{tabular}

\section{The Proposed Conceptual Framework}

The conceptual framework is developed to identify the dimensions that are related to the export market orientation (EMO), strategic alliance and international performance. This research proposed that EMO moderated by strategic alliance might be able to help the SMEs to succeed in international performance. However, there have been some researchers that questioned the values and universal benefits of $\mathrm{MO}$ whether this approaches truly benefited the firms or just simply cost of competing( Frösén et al., 2016; Kumar, Jones, Venkatesan, \& Leone, 2011). This is another question that would have to be answered and hence, warrant further investigation. It has been found that the ability to perform well in foreign markets is correlated with market orientation in the literature. (Boso, Cadogan, \& Story, 2013), while empirical evidence in the SME sector remains limited (Torres-Ortega, Rialp-Criado, \& RialpCriado, 2015) including for the effect of market orientation on the firm's export performance (Singh \& Mahmood, 2013), especially on the specific industry (Tuzová et al., 2017).

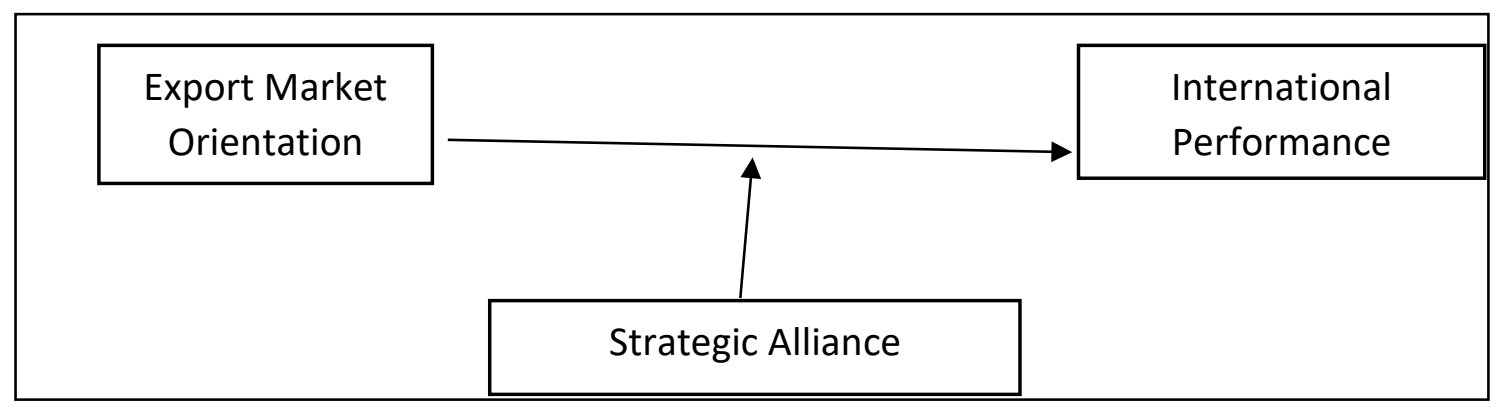

Figure 2: Proposed conceptual framework- dimensions of export market orientation (EMO), strategic alliance and international performance 


\section{Conclusion}

This conceptual paper focuses on the dimensions of export market orientation on the international performance. In addition, the conceptual framework focuses on the moderating role of strategic alliance. Based on the literature, EMO might have a positive relationship towards international performance. This suggests that EMO might be suitable for the success of Malaysian food industry in international performance. SMEs that improve their practices by using EMO might further excel in their international performances.

\section{References}

Bhuiyan, A. B., Said, J., Ismail, D., Fauzi, M., Jani, M., \& Gun, D. Y. (2016). The innovation drivers, strategies and performance of food processing SMEs in Malaysia. The Innovation Drivers, Strategies and Performance of Food Processing SMEs in Malaysia, 12(2), 154-166.

Blesa, A., \& Ripollés, M. (2008). The influence of marketing capabilities on economic international performance. International Marketing Review, 25(6), 651-673. https://doi.org/10.1108/02651330810915574

Bose, T. K. (2016). Critical success factors of SME internationalization. Journal of Small Business Strategy, 26(2), 87-109. Retrieved from https://search.proquest.com/central/docview/1792214530/fulltextPDF/E7D40DC8914 34DA3PQ/10?accountid $=43847$

Boso, N., Cadogan, J. W., \& Story, V. M. (2013). Entrepreneurial orientation and market orientation as drivers of product innovation success: A study of exporters from a developing economy. International Small Business Journal. https://doi.org/10.1177/0266242611400469

Brouthers, K. D., Nakos, G., \& Dimitratos, P. (2015). SME Entrepreneurial Orientation, International Performance, and the Moderating Role of Strategic Alliances. Entrepreneurship: Theory and Practice, 39(5), 1161-1187. https://doi.org/10.1111/etap.12101

Brouthers, L. E., Nakos, G., Hadjimarcou, J., \& Brouthers, K. D. (2009). Key factors for successful export performance for small firms. Journal of International Marketing, 17(3), 21-38. https://doi.org/10.1509/jimk.17.3.21

Cadogan, J. W., \& Diamantopoulos, A. (1995). Narver and slater, kohli and jaworski and the market orientation construct: Integration and internationalization. Journal of Strategic Marketing, 3(1), 41-60. https://doi.org/10.1080/09652549500000003

Cadogan, J. W., Kuivalainen, O., \& Sundqvist, S. (2009). Moderating Effects Under Differing Internationalization. Journal of International Marketing, 17(4), 71-89.

Chin, Y., \& Lim, E. (2018). Policies and Performance of SMEs in Malaysia. Journal of Southeast Asian Economies, 35(3), 470-487. Retrieved March 30, 2021, from https://www.jstor.org/stable/26545324

Coviello, N. E., McDougall, P. P., \& Oviatt, B. M. (2011). The emergence, advance and future of international entrepreneurship research? An introduction to the special forum. Journal of Business Venturing, 26(6), 625-631. https://doi.org/10.1016/j.jbusvent.2011.07.002

Eleventh Malaysia Plan. (2015). Eleventh Malaysia Plan 2016-2020. In Rancangan Malaysia Kesebelas (Eleventh Malaysia Plan): 2016-2020. Retrieved from http://rmk11.epu.gov.my/book/eng/Elevent-Malaysia-Plan/RMKe-11 Book.pdf

Fr, J., Luoma, J., Jaakkola, M., Tel, U. K., Tikkanen, H., Aspara, J., ... Laukkanen, M. (2016). What 
Counts Vs. What Can Be Counted: The Complex Interplay Of Market Orientation And Marketing Performance Measurement In Market Orientation And Marketing Performance Measurement In Organizational Configurations Abstract Market Orientation ( $\mathrm{MO}$ ) and ma. 1-60.

Franco, M., \& Haase, H. (2016). Internationalisation of born globals: the role of strategic alliances. European J. of International Management, 10(2), 181. https://doi.org/10.1504/EJIM.2016.074471

Glavas, C., Mathews, S., \& Bianchi, C. (2017). International opportunity recognition as a critical component for leveraging Internet capabilities and international market performance. Journal of International Entrepreneurship, 15(1), 1-35. https://doi.org/10.1007/s10843016-0191-y

Gregory, G. D., \& Richard, B. R. (1984). Measuring organizational performance in the absence of objective measures: The case of the privately-held firm and conglomerate business unit. Strategic Management Journal, 5(3), 265-273. https://doi.org/https://dx.doi.org/10.1002/smj.4250050306

Hashim, F. (2015). SMEs' impediments and developments in the internationalization process. World Journal of Entrepreneurship, Management and Sustainable Development, 11(2), 100-119. https://doi.org/10.1108/wjemsd-11-2013-0055

Ipek, I., \& Tanyeri, M. (2020). Home country institutional drivers and performance outcomes of export market orientation: the moderating role of firm resources. International Journal of Emerging Markets. https://doi.org/10.1108/IJOEM-10-2019-0803

Ismail, N. A., \& Kuivalainen, O. (2015). The effect of internal capabilities and external environment on small- and medium-sized enterprises' international performance and the role of the foreign market scope: The case of the Malaysian halal food industry. Journal of International Entrepreneurship, 13(4), 418-451. https://doi.org/10.1007/s10843-015-0160-x

Ismail, N. A., Mohamed, Z. A., \& Uli, J. (2013). The moderating effect of geographical scope on the relationship between managers' prior international knowledge and working experience and international performance in the Malaysian Halal Food Industry. Pertanika Journal of Social Science and Humanities, 21(SPEC. ISSUE), 115-132.

lurkov, V., \& Benito, G. R. G. (2018). Domestic alliance networks and regional strategies of MNEs: A structural embeddedness perspective. Journal of International Business Studies, 49(8), 1033-1059. https://doi.org/10.1057/s41267-017-0089-5

Kalinic, I., \& Forza, C. (2012). Rapid internationalization of traditional SMEs: Between gradualist models and born globals. International Business Review, 21(4), 694-707. https://doi.org/10.1016/j.ibusrev.2011.08.002

Kumar, V., Jones, E., Venkatesan, R., \& Leone, R. P. (2011). Is Market Orientation a Source of Sustainable Competitive Advantage or Simply the Cost of Competing? Journal of Marketing, 75(1), 16-30. https://doi.org/10.1509/jmkg.75.1.16

Leiblein, M. J., \& Reuer, J. J. (2004). Building a foreign sales base: The roles of capabilities and alliances for entrepreneurial firms. Journal of Business Venturing, 19(2), 285-307. https://doi.org/10.1016/S0883-9026(03)00031-4

Leonidou, L. C., Katsikeas, C. S., \& Coudounaris, D. N. (2010). Five decades of business research into exporting: A bibliographic analysis. Journal of International Management, 16(1), 7891. https://doi.org/10.1016/j.intman.2009.06.001

Lu, J. W., \& Beamish, P. W. (2001). The internationalization and performance of SMEs. Strategic Management Journal, 22(6-7), 565-586. https://doi.org/10.1002/smj.184 
Lu, Y., Zhou, L., Bruton, G., \& Li, W. (2010). Capabilities as a mediator linking resources and the international performance of entrepreneurial firms in an emerging economy. Journal of International Business Studies, 41(3), 419-436. https://doi.org/10.1057/jibs.2009.73

Madsen, T. K. (1989). Successful Export Marketing Management: Some Empirical Evidence. International Marketing Review, 6(4). https://doi.org/10.1108/EUM0000000001518

Malaysian Investment Development Authority. (2018). Food Industry In Malaysia. In Food Technology and Resources Based Industries Division, MIDA. Retrieved from http://www.mida.gov.my/home/administrator/system_files/modules/photo/uploads/ 20170906095028_SIB_Food Ind_Aug 2017_V4.pdf

Manimala, M. J., \& Kumar, S. (2012). Training Needs of Small and Medium Enterprises: Findings from an Empirical Investigation. IIM Kozhikode Society \& Management Review, 1(2), 97-110. https://doi.org/10.1177/2277975213477299

Milanov, H., \& Fernhaber, S. A. (2014). When do domestic alliances help ventures abroad? Direct and moderating effects from a learning perspective. Journal of Business Venturing, 29(3), 377-391. https://doi.org/10.1016/j.jbusvent.2013.05.004

Nakos, G., Dimitratos, P., \& Elbanna, S. (2018). The mediating role of alliances in the international market orientation-performance relationship of smes. International Business Review, (December), 1-10. https://doi.org/S0969593117307503

Narver, J. C., \& Slater, S. F. (1990). The Effect of a Mark et Orientation on Business. Journal of Marketing, (October), 20-35.

Olabode, O. E., Adeola, O., \& Assadinia, S. (2018). The effect of export market-oriented culture on export performance: Evidence from a Sub-Saharan African economy. International Marketing Review, 35(4), 637-660. https://doi.org/10.1108/IMR-08-2016-0167

Paochoo, R. (2016). Internationalization Performance of Thai Textile and Garment Smes : the Role of Organizational Capabilities.

Parise, S., \& Casher, A. (2003). Alliance portfolios : Designing and managing your network of business-partner relationships (Vol. 17).

Pascucci, F., Bartoloni, S., \& Gregori, G. L. (2016). Export market orientation and international performance in the context of SMEs. Journal of Small Business and Entrepreneurship, 28(5), 361-375. https://doi.org/10.1080/08276331.2016.1167528

Ren, S., Eisingerich, A. B., \& Tsai, H. (2015). How do marketing, research and development capabilities, and degree of internationalization synergistically affect the innovation performance of small and medium-sized enterprises ( SMEs )? A panel data study of Chinese SMEs. International Business Review, 24(4), 642-651. https://doi.org/10.1016/j.ibusrev.2014.11.006

Ribau, C. P., Moreira, A. C., Raposo, M., Scott-Kennel, J., Okpara, J. O., Kabongo, J. D., ... Yorkshire, W. (2017). Models of internationalisation: The New Zealand experience. International Journal of Business and Globalisation, 15(2), 528-554. https://doi.org/10.1504/IJBG.2013.052250

Sapienza, H. J., Smith, K. G., \& Gannon, M. J. (1988a). Using Subjective Evaluations of Organizational Performance in Small Business Research. American Journal of Small Business, 12(3), 45-54. https://doi.org/10.1177/104225878801200304

Sapienza, H. J., Smith, K. G., \& Gannon, M. J. (1988b). Using Subjective Evaluations of Organizational Performance in Small Business Research. American Journal of Small Business, 12(3), 45-54. https://doi.org/10.1177/104225878801200304

Shoham, A., Rose, G. M., \& Kropp, F. (2005). Market orientation and performance: A metaanalysis. Marketing Intelligence and Planning, 23(5), 435-454. 
https://doi.org/10.1108/02634500510612627

Singh, H., \& Mahmood, R. (2013). Determining the Effect of Export Market Orientation on Export Performance of Small and Medium Enterprises in Malaysia: An Exploratory Study. Advances in Management \& Applied Economics, 3(6), 223-232.

Tanvisuth, A. (2007). International entrepreneurship activities among Thai SMEs. (Publication No. 3273672) [Doctoral dissertation, University of Colorado]. ProQuest Dissertations \& Theses Global

Torres-Ortega, R., Rialp-Criado, A., Rialp-Criado, J. S. (2015). How to measure born-global firms' orientation towards international markets_ _ Elsevier Enhanced Reader.pdf. Revista Española de Investigación de Marketing ESIC, 19, 107-123.

Tuzová, M., Toulová, M., \& Kubíčková, L. (2017). The Specifics of the Internationalization Process of Czech SMEs in the Food Industry. Acta Universitatis Agriculturae et Silviculturae Mendelianae Brunensis, 65(3), 1055-1064. https://doi.org/10.11118/actaun201765031055

Vătămănescu, E. M., Alexandru, V. A., Mitan, A., \& Dabija, D. C. (2020). From the deliberate managerial strategy towards international business performance: A psychic distance vs. global mindset approach. Systems Research and Behavioral Science, 37(2), 374-387. https://doi.org/10.1002/sres.2658

Zain, Z. M., Anas, Y., Hassan, F. H., Lehar, H., \& Shamsuddin, S. (2012). Challenges, opportunities and performance of Bumiputera SMEs in the food industry: A Malaysian perspective. ICIMTR 2012 - 2012 International Conference on Innovation, Management and Technology Research, 722-726. https://doi.org/10.1109/ICIMTR.2012.6236489

Zhang, J., \& Zhu, M. (2016). Market orientation, product innovation and export performance: evidence from Chinese manufacturers. Journal of Strategic Marketing, 24(5), 377-397. https://doi.org/10.1080/0965254X.2015.1052538

Zhou, L., \& Wu, A. (2014). Earliness of internationalization and performance outcomes: EXPLORING the moderating effects of venture age and international commitment. Journal of World Business, 49(1), 132-142. https://doi.org/10.1016/j.jwb.2013.10.001 